\title{
ANALISIS SISTEM INFORMASI AKUNTANSI DAN SISTEM PENGENDALIAN INTERNAL PERSEDIAAN BARANG PADA TOKO CAMPLADEAN MANADO
}

\author{
Faujan Otinur ${ }^{1}$, Sifrid S. Pangemanan ${ }^{2}$, Jessy Warongan ${ }^{3}$ \\ 1,2,3 Jurusan Akuntansi, Fakultas Ekonomi dan Bisnis, Universitas Sam Ratulangi, J1. Kampus Unsrat Bahu, \\ Manado, 95115, Indonesia \\ Email : faujan.hino@gmail.com
}

\begin{abstract}
The accounting information system and the system of Internal control is a component that collect, classify, process, analyze and combine the relevant financial information for decision making the outside parties (suc as Government, community, investors, and creditors) parties in (especially management). Campladean Manado is a merchant selling sports equipment with various brands and types of goods so that it has a stockpile of goods quite a lot. This research aims to analyze accounting information systems inventory and enacted on Campaldean Manado. This research uses descriptive research method. Research results showed the accounting information system on Campladean Manado are still using manual systems of internal control systems but very helping and supporting accounting information systems in Manado in Campladean minimize the occurrence of errors in system of inventory items.
\end{abstract}

Keywords: Accounting information systems, Interalcontrol systems supplies.

\section{PENDAHULUAN}

Kemajuan teknologi informasi saat ini membuat dunia usaha diperhadapkan dengan situasi atau kondisi persaingan yang semakin ketat yang menuntut perusahaan untuk menjalankan usahanya lebih efektif dalam pencapaian tujuan perusahaan. Untuk perusahaan dagang pengendalian terhadap persediaan sangat diutamakan karena berbeda dengan perusahaan jasa yang tidak memiliki persediaan sehingga tidak membutuhkan kontrol terhadap persediaan.Adanya sistem informasi yang baik akan menghasilkan informasi yang sesuai dengan kebutuhan. Informasi yang baik merupakan informasi yang dapat disajikan tepat pada waktunya, bermanfaat dan dapat diandalkan. Salah satu sistem informasi yang penting dalam suatu perusahaan yaitu sistem informasi akuntansi.

Sistem informasi akuntansi adalah suatu komponen yang mengumpulkan, menggolongkan, mengolah, menganalisa, dan mengkombinasikan informasi keuangan yang relevan untuk pengambilan keputusan pihak-pihak luar (seperti pemerintah, masyarakat, investor, dan kreditor) pihak-pihak dalam (terutama manajemen). Selain itu sistem informasi juga berfungsi untuk menyediakan pengendalian yang memadai untuk menjaga aset-aset perusahaan. Pengawasan adalah fungsi manajemen yang bertujuan untuk mengusahakan agar aktivitas dapat berjalan selaras dengan perencanaan yang mengarah pada sasaran yang ditetapkan. Penyimpangan dari rencana dan tujuan merupakan hal yang harus dihindari karena akan menimbulkan penghamburan sumber daya yang pada gilirannya sedikit demi sedikit akan mengikis kemampuan financial perusahaan. Bilamana pengikisan itu terus berlanjut tanpa tertanggulangi, sudah dapat dipastikan bahwa organisasi perusahaan bersangkutan tidak akan dapat bertahan lebih lama lagi. Oleh karena itu penerapan sistem informasi akuntansi yang efektif dalam suatu perusahaan akan memberikan banyak manfaat bagi perusahaan dan manajemen dalam menjalankan usahanya, baik perusahaan yang bergerak dibidang dagang, manufaktur maupun jasa. 
Campladean Manado merupakan perusahan dagang yang menjual sepatu, tas, sleyer, topi, ikat pinggang, serta perlengkapan olahraga dan macam-macam barang dengan spesifikasi merek Outdorsport dimana Campalaiden Manado bertindak sebagai pedagang satuan serta distributor untuk merek Outdorsport. Selain spesifikasi merek Outdorsport ada juga barang yang sama dengan merek Eiger dan Torch. Dengan berbagai merek barang dagang membuat kerentanan kesalahan terhadap pencatatan persediaan, perlunya pengendalian serta sistem yang jelas untuk memastikan persediaan barang dagangan Campladean Manado tidak mengalami ketekoran barang.

Untuk mengatasi masalah ini diperlukan suatu pengelolaan dagangan yang baik. Pengelolaan yang baik dibutuhkan suatu penyusunan sistem informasi yang berperan dalam menangani keamanan persediaan bagi perusahaan. Sehingga tujuan dari penelitian ini adalah untuk menganalisis apakah sistem informasi akuntansi persediaan, serta sistem pengendalian internal pada toko Campladean Manado sudah diterapkan dengan efektif dan efisien.

\section{TINJAUAN PUSTAKA}

\subsection{Pengertian Sistem Informasi Akuntansi)}

1. Menurut Krismiaji (2010 : 4), sistem informasi akuntansi adalah "sebuah sistem yang memproses data dan transaksi guna menghasilkan informasi yang bermanfaat untuk merencanakan, mengendalikan, dan mengoperasikan bisnis".

2. Sedangkan menurut Baridwan (2013 : 4), sistem informasi akuntansi adalah "suatu komponen yang mengumpulkan, menggolongkan, mengolah, menganalisa, dan mengkombinasikan informasi keuangan yang relevan untuk pengambilan keputusan pihak-pihak luar (seperti pemerintah, masyarakat, investor, dan kreditor) pihak-pihak dalam (terutama manajemen)".

\subsection{Persediaan}

Menurut Soemarso (2009), persediaan barang dagang adalah barang-barang yang dimilki perusahaan untuk dijual kembali. Persediaan pada umunya meliputi jenis barang yang cukup banyak dan merupakan bagian yang cukup berarti dari seluruh aktiva perusahaan.Disamping itu transaksi yang berhubungan dengan perusahaan merupakan aktivitas yang paling sering terjadi.

\subsection{Metode pencatatan persediaan}

Persediaan memegang peranan yang sangat penting untukmenentukan hasil usaha atau pendapatan, (harga pokok barang yang terjual).Harus diketahui terlebih dahulu jumlah pembeliannya bersih persediaanpada awal periode akuntansi. Menurut Zaki Baridwan (2013) terdapat 2 macam metode pencatatan persediaan yaitu :

a. Sistem Periodik (fisik)

Penilaian persediaan dilakukan dengan menggunakan perhitungansecara fisik.Pencatatan transaksi persediaan barang dagangan dengan metode ini tidak langsung berkaitan dengan barang dagang yang bersangkutan. Misalnya bila terjadi pembelian barang dagangan akan dicatat pada rekening khusus yaitu pembelian (purchases) dan penjualan barang dagangan dicatat pada rekening penjualan. Pada waktu terjadi pembelian atau penjualan tidak dicatat rekening persediaan. Metode yang digunakan dalam sistem periodik antara lain

1. Metode Tanda Pengenalan Khusus

Metode ini biasanya digunakan untuk perusahaan yang spesifik danspesial yang menjual barang sedikit dan harga mahal.Setiap barangyang masuk diberi tanda pengenal khusus yang menunjukan harga satuan sesuai dengan faktur pembelian yang diterima.

2. Metode Rata-Rata

Cara penghitungan metode ini adalah dengan menghitung rata-rata dari harga beli dari jumlah yang dibeli selama periode tertentu.

3. Metode First In First Out (FIFO) 
Dalam metode First In First Out(FIFO), barang yang lebih dulu masuk dianggap barang yang lebih dahulu keluar.

4. Metode Last In First Out (LIFO)

Dalam metode Last In First Out(LIFO), barang yang terakhir masuk dianggap barang yang terlebih dahulu keluar.

5. Metode Persediaan Dasar

Adakalanya perusahaan menetapkan jumlah minimum persediaan yang harus ada setiap saat, baik mengenai kuantitas maupun harga satuan, atau sering disebut persediaan dasar (basic stock).Menurut metode ini, nilai persediaan barang akhir periode dihitung:

a. Apabila kuantitas lebih banyak daripada kuantitas sediaan dasar,nilai persediaan adalah nilai dasar ditambah dengan harga pasar kelebihannya.

b. Apabila kuantitas lebih rendah daripada kuantitas sediaan dasar,nilai persediaan adalah nilai dasar dikurangi dengan harga pasar kekurangannya.

a. Apabila kuantitas lebih banyak daripada kuantitas sediaan dasar,nilai persediaan adalah nilai dasar ditambah dengan harga pasar kelebihannya.

b. Apabila kuantitas lebih rendah daripada kuantitas sediaan dasar,nilai persediaan adalah nilai dasar dikurangi dengan harga pasar kekurangannya.

\subsection{Tujuan dan Manfaat Sistem Informasi Akuntansi}

Diana dan Setiawati (2011 : 5) menyatakan bahwa tujuan atau manfaat sistem informasi akuntansi adalah sebagai berikut.

1. Mengamankan harta/kekayaan perusahaan. Harta kekayaan yang dimaksud meliputi kas perusahaan, persediaan barang dagangan, termasuk aset tetap perusahaan.

2. Mengahasilkan beragam informasi untuk pengambilan keputuasan.

3. Mengahasilkan informasi untuk pihak eksternal.

4. Menghasilkan informasi untuk penilaian kinerja karyawan atau divisi.

5. Menyediakan data masa lalu untuk kepentingan audit (pemeriksaan).

6. Menghasilkan informasi untuk penyusunan dan evaluasi anggaran perusahaan.

7. Menghasilkan informasi yang diperlukan dalam kegiatan perencanaan dan pengendalian.

Berdasarkan definisi sistem informasi akuntansi maka tujuan dan manfaat sistem informasi akuntansi tersebut adalah sebagai pengolah transaksi (transaction processing) dan pengolah informasi (information processing).

1. Pemrosesan Transaksi

Transaksi memungkinkan perusahaan melakukan operasi, menyelenggarakan arsip dan catatan up on date, dan mencerminkan aktivitas organisasi. Transaksi akuntansi merupakan transaksi pertukaran yang mempunyai nilai ekonomis. Tipe transaksi dasar adalah : (1) penjualan produk atau jasa, (2) pembelian bahan baku, barang dagangan, jasa, dan aset tetap dari suplier, (3) penerimaan kas, (4) pengeluaran kas kepada suplier, dan (5) pengeluaran kas gaji karyawan. Sebagai pengolah transaksi, sistem informasi akuntansi berperan mengatur dan mengoperasionalkan semua aktivitas transaksi perusahaan.

2. Pengolahan Transaksi

Tujuan kedua sistem informasi akuntansi adalah untuk menyediakan informasi yang diperlukan dalam pengambilan keputusan yang dilaksanakan oleh aktivitas yang disebut pemrosesan transaksi. Sebagian keluaran yang diperlukan oleh pemrosesan transaksi disediakan oleh sistem pemrosesan transaksi. Namun sebagian besar diperoleh dari sumber lain, baik dari dalam maupun dari luar perusahaan. Pengguna utama pemrosesan transaksi adalah manajer perusahaan. Mereka mempunyai tanggung jawab pokok untuk mengambil keputusan yang berkenaan dengan perencanaan dan pengendalian operasi perusahaan. Pengguna output lainnya adalah para karyawan penting seperti akuntan, insinyur, serta pihak luar seperti investor dan kreditor. 


\subsection{Prinsip Dasar Pengendalian Internal}

a. Ada beberapa asumsi dasar yang perlu dipahami mengenai pengendalian intern bagi suatu entitas organisasi atau perusahaan.

b. Menurut Sanyoto (2007 : 256)Sistem pengendalian internal merupakan management responsibility. Bahwa sesungguhnya yang paling berkepentingan terhadap sistem pengendalian internal suatu entitas organisasi/ perusahaan adalah manajemen (lebih tegasnya lagi ialah top management / direksi), karena dengan sistem pengendalian internal yang baik itulah top management dapat mengharapkan kebijakan dipatuhinya, aktiva atau harta perusahaan dilindungi, dan penyelenggaraan pencatatan berjalan baik.

c. Hasil perhitungan kas direkam dalam berita acara penghitungan kas dan disetor penuh ke bank dengan segera

d. Para penagih dan kasir harus diasuransikan (fidelity bond insurance)

e. Kas dalam perjalanan (baik yang ada ditangan bagian kasir maupun di tangan penagih perusahaan) harus diasuransikan (Cash-in-safe dan cash-in-transit Insurance)

\subsection{Komponen Pengendalian Internal}

Pengendalian internal dalam suatu perusahaan sangat berguna dalam pengawasan harta kekayaan perusahaan. Agar tujuan sistem pengendalian internal perusahaan dapat dicapai dengan baik, maka selayaknya mempertimbangkan unsur-unsur atau komponen dari sistem pengendalian internal tersebut. Komponen pengendalian internal COSO terdiri dari hal-hal berikut :

1. Lingkungan Pengendalian

Lingkungan Pengendalian terdiri dari tindakan, kebijakan dan prosedur yang menggambarkan keseluruhan sikap manajemen, direksi, dan pemilik dari suatu entitas atas pengendalian internal dan pentingnya pengendalian internal tersebut terhadap entitas. Untuk memahami dan menilai lingkungan pengendalian, auditor harus mempertimbangan subkomponen pengendalian internal yang sangat penting :

a) Integritas dan Nilai Etika

b) Komitmen Terhadap Kompotensi

c) Partisipasi Dewan Direksi dan Komisaris atau Komite Audit

d) Filosofi Manajemen dan Gaya Operasi

e) Struktur Organisasi

f) Kebijakan dan Praktik Sumber Daya Manusia

2. Penilaian Risiko

Penilaian resiko untuk laporan keuangan merupakan identifikasi dan analisis manajemen terhadap risiko-risiko yang relevan terhadap penyusunan laporan keuangan sesuai dengan PABU. Proses penilaian risiko yaitu mengidentifikasi faktor-faktor yang memengaruhi risiko, menilai pentingnya risiko dan kemungkinan terjadinya, serta menentukan tindakan-tindakan yang perlu dilakukan untuk menangani risiko.

3. Aktivitas Pengendalian

Aktivitas pengendalian merupakan kebijakan dan prosedur, selain yang telah dimaksudkan dalam keempat komponen lainnya, yang membantu untuk meyakinkan bahwa tindakan-tindakan yang penting telah dilakukan untuk mengatasi risiko-risiko dalam mencapai tujuan organisasi. Terdapat kemungkinan banyak aktivitas pengendalian pada setiap entitas, termasuk pengendalian secara manual dan pengendalian secara otomatis. Aktivitas pengendalian tersebut umumnya termasuk kedalam salah satu dari kelima jenis aktivitas berikut :

a) Pemisahan tugas yang memadai.

b) Otorisasi yang tepat atas transaksi dan aktivitas. 
c) Dokumentasi dan catatan yang memadai.

d) Pengendalian fisik atas aset dan catatan-catatan.

e) Pengecekan terhadap pekerjaan secara independen.

4. Informasi dan Komunikasi

Tujuan dari sistem informasi dan komunikasi akuntansi suatu entitas adalah untuk memulai, mencatat, memproses, dan melaporkan transaksi-transaksi yang terjadi dalam suatu entitas dan untuk menjaga akuntabilitas aset-aset yang terkait. Sebuah sistem informasi dan komunikasi akuntansi memiliki beberapa subkomponen, biasanya membentuk suatu kelompok transaksi seperti penjualan, retur penjualan, penerimaan kas, pembelian dan lainlain. Untuk setiap kelompok transaksi, sistem akuntansi harus memenuhi keenam tujuan audit terkait transaksi seperti keterjadian, kelengkapan, akurasi, pemindahbukuan dan pengikhtisaran, klasifikasi, dan waktu.

5. Pengawasan

Aktivitas pengawasan berkaitan dengan penilaian yang berjalan atau penilaian berkala atas kualitas pengendalian internal oleh manajemen untuk menentukan bahwa pengendalian dijalankan sesuai dengan tujuannya dan dimodifikasi jika diperlukan terjadi perubahan kondisi. Informasi yang dinilai berasal dari berbagai sumber, termasuk studi atas pengendalian internal yang sudah ada, laporan internal auditor, laporan pengecualian atas aktivitas pengendalian, laporan dari regulator misalnya dari regulator perbankan, umpan balik dari personel operasi, dan keluhan-keluhan dari pelanggan mengenai biaya penagihan. Untuk beberapa perusahaan, biasanya perusahaan besar, departemen audit internal merupakan fungsi penting untuk melakukan pengawasan efektif.

Agar menjadi efektif, fungsi pengendalian internal harus dijalankan oleh staf yang independen dari departemen operasi maupun dari departemen akuntansi dan melaporkan langsung kepada otoritas yang lebih tinggi dalam organisasi, apakah pada manajemen puncak atau pun pada komite audit dari dewan direksi.

Mulyadi (2015:164) menyatakan bahwa unsur pokok sistem pengendalian intern adalah :

1. Struktur Organisasi Yang Memisahkan Tanggung Jawab Fungsional Secara Tegas.

Pembagian tanggung jawab fungsional dalam organisasi ini didadasarkan pada prinsip-prinsip berikut ini:

a) Harus dipisahkan fungsi-fungsi operasi dan penyimpanan dari fungsi akuntansi.

b) Suatu fungsi tidak boleh diberi tangung jawab penuh untuk melaksanakan seluruh tahap suatau transaksi.

2. Sistem Wewenang dan Prosedur Pencatatan Yang Memberikan Perlindungan Yang Cukup Terhadap Kekayaan, utang, pendapatan, biaya.

Dalam organisasi, setiap transaksi hanya terjadi atas dasar otoritas dari pejabat yang memiliki wewenang untuk menyetujui terjadinya transaksi tersebut. Oleh karena itu, dalam organisasi harus dibuat sistem yang mengatur pembagian wewenang untuk otorisasi atas terlaksananya setiap transaksi. Prosedur pencatatan yang baik akan menjamin data yang direkam dalam formulir dicatat dalam catatan akuntansi dengan tingkat ketelitian dan keandalannya yang tinggi.

3. Praktik Yang Sehat Dalam Melaksanakan Tugas Dan Fungsi Setiap Unit Organisasi.

Adapun cara-cara yang umumnya ditempuh oleh perusahaan dalam menciptakan praktik yang sehat adalah :

a) Penggunaan formulir bernomor urut tercetak yang pemakaiannya harus dipertanggungjawabkan oleh yang berwenang.

b) Pemeriksaan mendadak (surprised audit),

c) Setiap transaksi tidak boleh dilaksanakan dari awal sampai akhir oleh satu orang atau satu unit organisasi, tanpa ada campur tangan dari orang atau unit organisasi lain,

d) Perputaran jabatan (job rotation), 
e) Keharusan pengambilan cuti bagi karyawan yang berhak,

f) Secara periodik diadakan pencocokan fisik kekayaan dengan catatannya,

g) Pembentukan unit organisasi yang bertugas untuk mengecek efektivitas unsur-unsur sistem pengendalian intern yang lain.

4. Karyawan Yang Mutunya Sesuai Dengan Tanggung Jawabnya.

Untuk mendapatkan karyawan yang kompoten dan dapat dipercaya, berbagai cara berikut ini dapat ditempuh:

a) Seleksi calon karyawan berdasarkan persyaratan yang dituntut oleh pekerjaannya,

b) Pengembangan pendidikan karyawan selama menjadi karyawan perusahaan, sesuai dengan tuntutan perkembangan pekerjaannya.

\section{METODE PENELITIAN}

\section{Jenis Penelitian}

Jenis penelitian yang digunakan dalam penelitian ini adalah metode penelitian deskriptif kualitatif. Penelitian dilakukan pada kondisi yang alamiah langsung ke sumber data, pengumpulan data menggunakan instrumen penelitian dan data yang terkumpul berupa profil perusahaan, visi dan misi perusahaan, struktur organisasi, job description, serta prosedur pencatatan persediaan pada Toko Campladean Manado.

\section{Tempat dan Waktu Penelitian}

Lokasi penelitian bertempat di Toko Campladean Manado. Waktu penelitian yang ditentukan selama 3 bulan yaitu pada bulan Februari sampai dengan Juni 2016.

\section{Metode Pengumpulan Data}

Metode yang digunakan dalam pengumpulan data meliputi:

1. Observasi, merupakan teknik yang dilakukan untuk mengetahui keadaan dan masalah yang dihadapi oleh perusahaan.

2. Wawancara, yaitu teknik pengumpulan data dimana peneliti mengajukan pertanyaan tentang segala sesuatu kepada pemimpin dan karyawan perusahaan yang bersangkutan. Teknik wawancara ini digunakan untuk memperoleh data secara langsung mengenai sistem persediaan barang.

3. Dokumentasi, yaitu suatu usaha yang dilakukan dalam kajian untuk mengumpulkan data-data yang menyangkut penelitian ini, dengan cara menggunakan dokumen yang tersedia sebagai sumber informasi untuk mencapai tujuan yang diharapkan. Metode dokumentasi ini digunakan untuk memperoleh data yang dibutuhkan secara langsung dari teknik wawancara mengenai sistem persediaan barang pada Campaliden Manado.

\section{Metode Analisis}

Metode analisis yang digunakan adalah analisis deskriptif yaitu suatu metode pembahasan yang bersifat menguraikan, menggambarkan, membandingkan, dan menerangkan suatu data atau keadaan sehingga dapat ditarik suatu kesimpulan untuk menjawab permasalahan dalam penelitian.

\section{HASIL PENELITIAN DAN PEMBAHASAN}

\subsubsection{Sistem Informasi Akuntansi Persediaan Barang Campladean Manado.}

Sistem Infomasi Akuntansi persediaan ditunjukan untuk mengamankan persediaan yang mungkin terjadi seperti penyelewengan dan kecurangan yang dilakukan oleh suatu bagian.Berdasarkan hasil penelitian pada Campladean Manado Sistem Informasi Akuntansi Persediaan Campladean Manado meliputi sistem secara manual.Kegiatan sistem informasi akuntansi persediaan barang Campladean Manado digambarkan dalam alur bagan flowchart dibawah ini: 
a. Alur Pembelian Barang
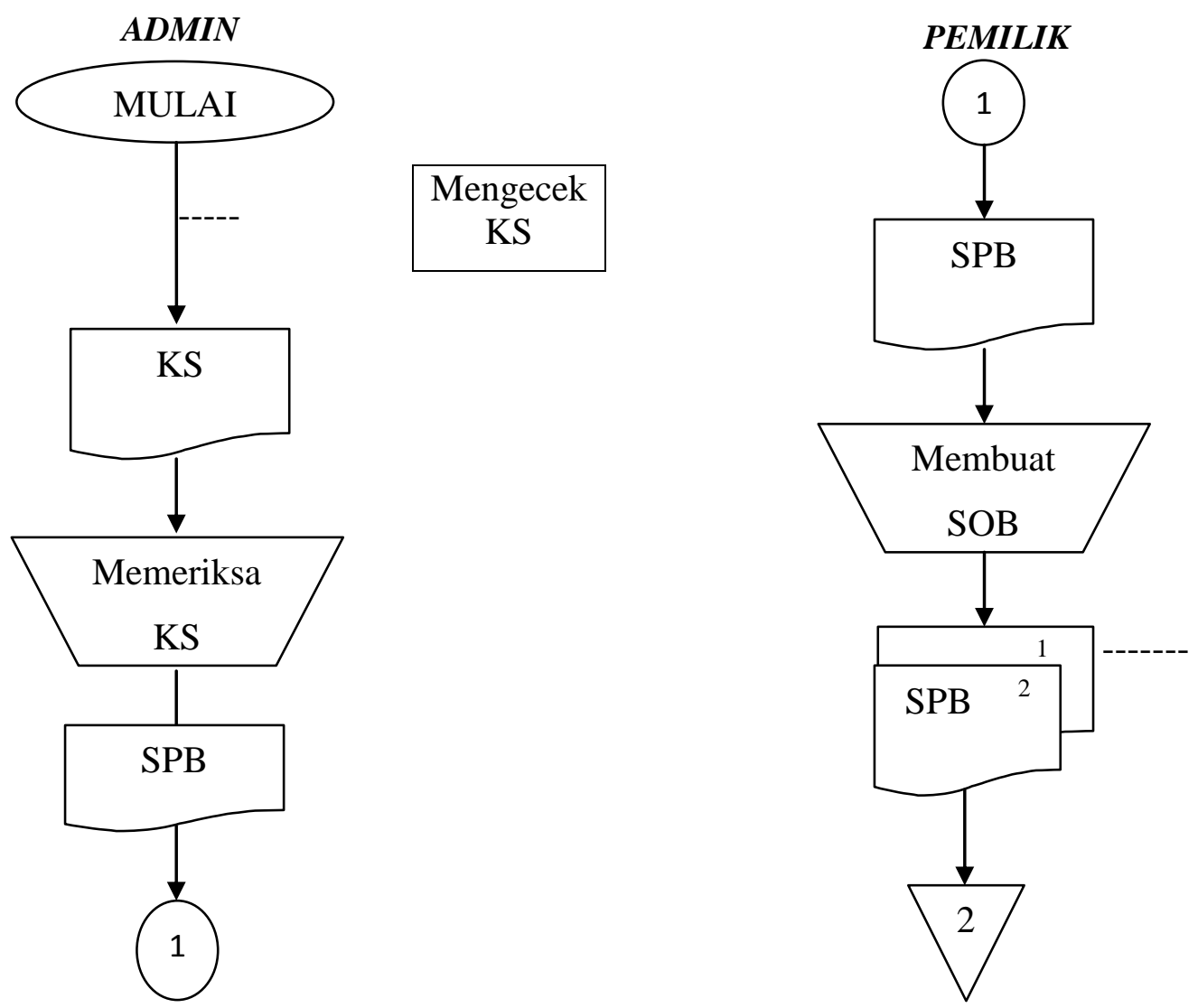

Diberikan ke supplier

Sumber : Olahan Sendiri berdasarkan penelitian (2017)

Berdasarkan Gambar 4.5 maka uraian atas sistem pembelian barang adalah :

Administrasi:

1. Mengecek Kartu Stock

2. Memeriksa barang -barang apa yang harus di order.

3. Membuat Surat Permintaan Barang

Pemilik:

1. Menerima Surat Permintaan Barang dari Admin

2. Membuat 2 Surat Order Barang ke supplier dan

3. Surat Order Barang : 1. Untuk Supplier ; 1 untuk Administrasi sebagai arsip 


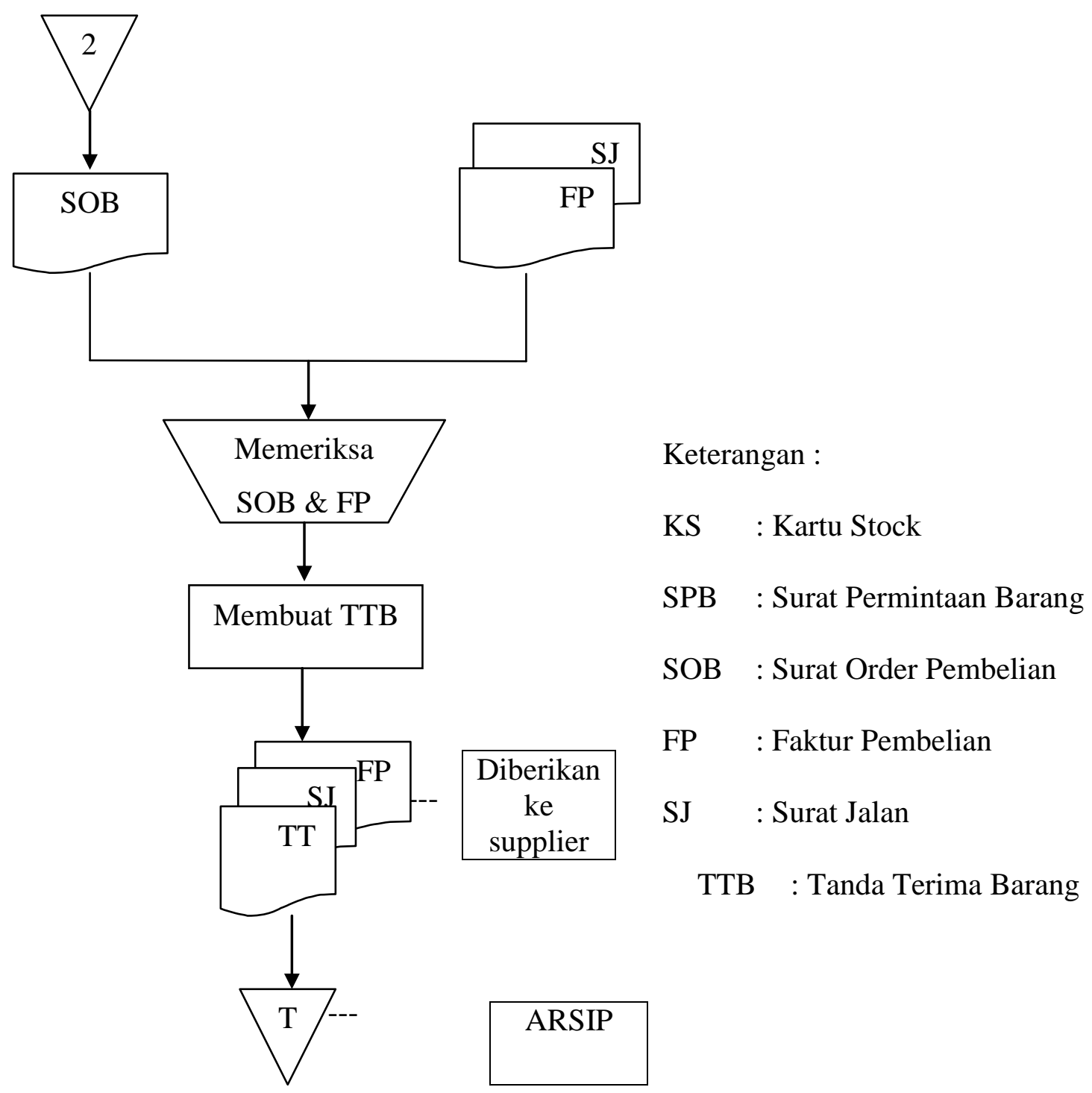

Gambar 4.6. Flowchart Alur Penerimaan

Sumber : Olahan Sendiri berdasarkan penelitian (2016)

Berdasarkan Gambar 4.6 maka uraian atas sistem penerimaan barang adalah :

\section{Admin:}

1. Arsip Surat Order Barang dan Faktur Penjualan dari supplier dicocokan apakah sama

2. Memeriksa Faktur Penjualan dari supplier dengan fisik barang yang diterima

3. Membuat tanda terima barang

4.Mengarsip semua dokumen

Administrasi bertanggung jawab untuk sediaan barang dagangan. Sebelum melakukan order barang administrasi mengecek Kartu Stock (KS), kemudian memeriksa kartu stock barang-barang yang harus di order. Selanjutnya administrasi membuat Surat Permintaan Barang ke supplier (SPB). Surat Permintaan Barang diserahkan ke Owner/Pemilik untuk ditinjau dan disetujui, setelah disetujui oleh owner/pemilik, selanjutnya owner/pemilik mengeluarkan 2 rangkap Surat Order Barang dimana rangkap 1 untuk diserahkan ke supplier dan rangkap 2 untuk bangian administrasi. 
Untuk penerimaan barang administrasi yang bertanggungjawab untuk menerima barang dari supplier berdasarkan Arsip Surat Order Barang yang dicocokan dengan Faktur Pembelian (FP) dan Surat Jalan (SJ) dari supplier.Administrasi membuat Tanda Terima Barang (TTB) jika fisik barang telah sesuai dengan Surat Order Barang, Faktur Pembelian dan Surat Jalan yang ada.

\section{Analisis Sistem Pengendalian Internal Campladean Manado}

Menurut Sanyoto (2007 : 256) Sistem pengendalian internal merupakan management responsibility. Bahwa sesungguhnya yang paling berkepentingan terhadap sistem pengendalian internal suatu entitas organisasi/ perusahaan adalah manajemen (lebih tegasnya lagi ialah top management / direksi), karena dengan sistem pengendalian intern yang baik itulah top management dapat mengharapkan kebijakan dipatuhinya, aktiva atau harta perusahaan dilindungi, dan penyelenggaraan pencatatan berjalan baik.

Pengendalian internal dalam suatu perusahaan sangat berguna dalam pengawasan harta kekayaan perusahaan. Agar tujuan sistem pengendalian internal perusahaan dapat dicapai dengan baik, maka selayaknya mempertimbangkan unsur-unsur atau komponen dari sistem pengendalian internal. Dimana sistem pengendalian internal pada Campladean Manado telah diberlakukan berdasarkan komponen pengendalian internal.

\section{a. Lingkungan Pengendalian}

Menurut Hartadi (2010) Lingkungan pengendalian terdiri dari tindakan, kebijakan dan prosedur yang menggambarkan keseluruhan sikap manajemen, direksi dan pemilik dari suatu entitas atas pengendalian internal.

Aktivitas pengendalian persediaan Campladean Manado meliputi kebijakan dan prosedur yang dibuat oleh pemilik toko untuk memberikan kemungkinan yang memadai bahwa system pengendalian persediaan barang dagangan yang diterapkan telah dilksanakan dalam beberapa kategori :

\section{Pemisahan tugas yang cukup}

Pada aktifitas penjualan, order, pembelian serta penerimaan barang semua aktifitas berjalan sesuai prosedur yang ada.Sehingga semua tertangani dengan baik.

2. Otorisasi atas transaksi dan aktivitas:

Dalam setiap keputusan mengenai aktivitas toko harus berkoordinasi dengan pemilik toko.Serta keputusan akhir melalui persetujuan pemilik toko. Untuk persediaan barang Campladean Manado Administrasi melaporkan barang-barang yang kurang, pemilik toko yang memutuskan barang-barang apa saja yang akan di order.

\section{b. Penilaian Resiko}

Proses penilaian resiko yaitu mengidentifikasi faktor-faktor yang mempengaruhi resiko, menilai pentingnya resiko dan kemungkinan terjadinya, serta menentukan tindakantindakan yang perlu dilakukan untuk menangani resiko (Hartadi, 2010) .Penilaian resiko untuk meminimalisir terjadinya kerugian perusahaan dilakukan Campladean Manado cukup baik dilihat dari perlakuan system persediaan menggunakan system FIFO (First in First Out).Dimana barang yang pertama masuk menjadi barang pertama keluar.Walaupun Campladean Manado merupakan toko barang-barang yang tidak memiliki resiko kadaluarsa namun penggunaan Sistem FIFO mengurangi resiko kerusakan barang, yang terjadi karena rayap ataupun penyusutan barang karena kondisi gudang yang tertutup dan lembap. Stock Opname diberlakukan setiap akhir bulan dengan maksud memastikan kondisi fisik stock dengan pencatatan persediaan barang yang ada. hal ini juga mengurangi resiko terjadinya penyelewengan karyawan terhadap barang-barang sediaan toko.

\section{c. Aktivitas Pengendalian}

Aktivitas pengendalian merupakan kebijakan dan prosedur, selain yang telah dimaksudkan dalam keempat komponen lainnya, yang membantu untuk meyakinkan bahwa 
tindakan-tindakan yang penting telah dilakukan untuk mengatasi resiko-resiko dalam mencapai tujuan organisasi.

Dalam prakteknya aktifitas pengendalian pada Campladean Manado dilakukan berdasarkan tugas dan tanggung jawab masing-masing bagian dalam pengawasan langsung pemilk toko.hal ini untuk menunjang aktivitas pengendalian yang baik dalam Campladean Manado.

\section{d. Informasi dan Komunikasi}

Tujuan dari sistem informasi dan komunikasi akuntansi suatu entitas adalah untuk memulai, mencatat, memproses, dan melaporkan transaksi-transaksi yang terjadi dalam suatu entitas untuk menjaga akuntabilitas asset-asset yang terkait.

Campaldean Manado memastikan pengendalian dalam Informasi dan komunikasi berjalan baik dimana setiap bagian bertanggung jawab melaporkan laporan sesuai dengan tanggungjawab masing-masing. Setiap bagian memiliki tanggung jawab dan dilaporkan dalam bentuk laporan.Baik kasir, administrasi bahkan pramuniaga memiliki kewajiban untuk melaporkan kegiatan yang dilakukan.

\section{e. Pengawasan}

aktivitas pengawasan berkaitan dengan penilaian yang berjalan atau penilaian berkala atas kualitas pengendalian internal oleh manajemen untuk menenukan bahwa pengendalian intern dijalankan sesuai dengan tujuan dan dimodifikasi jika diperlukan terjadi perubahan kondisi. Pengawasan Campladean cukup baik dimana struktur organisasi begitu sederhana, sehingga job description toko dijalankan secara efisien dan adanya pengawasan langsung oleh pemilik sehingga memiliki otorisasi penuh untuk setiap informasi yang dilaporkan ke pemilik toko, dan segala tindakan yang diambil berdasarkan keputusan pemilik toko.

\section{KESIMPULAN DAN SARAN \\ Kesimpulan}

Kesimpulan penelitian ini adalah:

1. Campladean Manado telah mempunyai struktur organisasi yang memadai sesuai dengan kebutuhan. Selain itu struktur organisasinya didukung dengan uraian tugas, fungsi dan tanggung jawab untuk setiap bagian dalam melaksanakan tugas dan tanggung jawabnya masing-masing.

2. Penerapan sistem informasi akuntansi persediaan barang Campladean Manado sudah memadai didukung dengan adanya sistem dan pencataan yang baik. Sistem informasi persediaan barang yang digunakan adalah secara manual. Akan tetapi tidak menurunkan keefektivan dari sistem informasi yang diterapkan dan tetap masih terkontrol dengan baik.

3. Pengendalian intern yang diterapkan di Campladean Manado sudah sesuai dengan unsurunsur pengendalian internal, dimana terdapat pembagian tugas yang jelas untuk membantu pengendalian internal Campladean Manado. Selain itu setiap bagian telah memiliki koordinator yang dapat membantu Owner dalam mengontrol setiap aktivitas toko agar tidak terjadi kesalahan atau penyelewengan.

\section{Saran}

Saran yang dapat diberikan:

1. Sebaiknya sistem informasi akuntansi pada bagian persediaan memberlakukan sistem informasi secara komputerisasi sesuai dengan sistem informasi akuntansi yang dibutuhkan, agar lebih mempermudah proses pencatatan. Namun, bukan berarti sistem informasi secara manual yang telah diterapkan harus dihilangkan, tetapi sistem informasi akuntansi secara manual tersebut tetap dijadikan sebagai dokumen pendukung. Sehingga mempermudah 
bagian akuntansi untuk mengatasi terjadinya kesalahan dalam pencatatan maupun hal-hal lain yang dapat mendukung aktivitas Campladean Manado.

2. Pengendalian Internal yang diberlakukan Campladean Manado sebaiknya terus ditingkatkan untuk tetap menjaga penerimaan dan pencatatan persediaan sesuai prosedur dan mencegah terjadinya ketekoran yang merugikan.

\section{DAFTAR PUSTAKA}

Baramuli, Friska, 2015,“Analisis Sistem Informasi Akuntansi Persediaan pada Yamaha Bima Motor Toli-Toli”. Jurnal EMBA 2303-1174 Vol. 3. No. 1.2302-1175,Fakultas Ekonomi dan Bisnis Universitas Sam Ratulangi. Manado.

Baridwan, Zaki, 2013. Sistem Informasi Akuntansi. Edisi Kedua. Salemba Empat. Jakarta.

Diana Anastasia, Setiawati Lilis. 2011. Sistem Informasi Akuntansi. Edisi Kesatu. Penerbit Andi. Yogyakarta.

Hartadi, Bambang, 2010. Sistem Pengendalian Intern dalam Hubungannya dengan Manajemen dan Audit. Penerbit Fakultas Ekonomu. Yogyakarta.

Ikatan Akuntan Indonesia. 2015. Akuntansi Dasar (Sesuai dengan PSAK terkini). Penerbit Ikatan Akuntan Indonesia.

Krismiaji. 2010. Sistem Informasi Akuntansi. Edisi Keempat. UPP AMP YPKN. Yogyakarta.

Manopo, Gracias, 2016, "Evaluasi Penerapan Sistem Informasi Akuntansi Atas Siklus Pendapatan pada PT. PLN (PERSERO) Manado" Journal EMBA Vol.4 No.1, 743859.

Mulyadi. 2015. Sistem Akuntansi. Edisi Keempat. Salemba Empat. Jakarta.

Soemarso, S.R. 2009. Akuntansi Suatu Pengantar. Edisi Lima. Salemba Empat. Jakarta.

Sugiyono. 2010. "Metode Penelitian Bisnis". Penerbit Alfabet, Bandung. 